\title{
Denitrification measurements of sediments using cores and chambers
}

\author{
Peter I. Macreadie ${ }^{1, *}$, D. Jeff Ross ${ }^{1}$, Andrew R. Longmore ${ }^{2}$, Michael J. Keough ${ }^{1}$ \\ ${ }^{1}$ Department of Zoology, The University of Melbourne, Victoria 3010, Australia \\ ${ }^{2}$ Marine and Freshwater Systems, Primary Industries Research Victoria, PO Box 114, Queenscliff, \\ Victoria 3225, Australia
}

\begin{abstract}
Denitrification is commonly measured using in situ benthic chambers or laboratory incubations of sediment cores. These techniques are similar in principle but differ considerably in cost and practicality. Despite widespread use of both techniques, it is uncertain whether they give comparable results. We compared cores and chambers for measuring fluxes (dissolved oxygen [DO], $\mathrm{N}_{2}$, $\mathrm{NH}_{4}{ }^{+}, \mathrm{NO}_{3}{ }^{-}$and $\mathrm{NO}_{2}{ }^{-}$) and denitrification efficiency at 2 sites in Port Phillip Bay, Victoria, Australia. Overall, denitrification efficiency was not significantly different between cores and chambers, but fluxes of $\mathrm{DO}, \mathrm{NO}_{3}{ }^{-}$and $\mathrm{NO}_{2}{ }^{-}$differed. Chambers demonstrated higher levels of oxygen consumption and net fluxes of $\mathrm{NO}_{3}{ }^{-}$and $\mathrm{NO}_{2}{ }^{-}$out of the sediment, suggesting that denitrification and nitrification were closely coupled. In contrast, there was a greater relative importance for uncoupled denitrification in cores as indicated by reduced oxygen consumption and net fluxes of $\mathrm{NO}_{3}{ }^{-}$into the sediment. We conclude that cores and chambers give different flux results and therefore are not comparable techniques for measuring denitrification. To ascertain the cause of this, we tested the hypothesis that cores failed to adequately incorporate the impacts of macrofauna on fluxes, due to the small size of cores relative to chambers. However, densities of macrofauna were not significantly different in cores and chambers. We then hypothesised that disturbance during core collection, transportation, and handling may account for differences, but cores deployed in situ and in the laboratory gave similar results. We suggest that compression of sediment during insertion of core cylinders into the sediment may account for differences between core and chamber fluxes.
\end{abstract}

KEY WORDS: Denitrification - Benthic chambers - Sediment cores $\cdot$ Nutrient flux - Macrofauna · Disturbance · Port Phillip Bay

\section{INTRODUCTION}

In many coastal water bodies, denitrification is the major pathway for nitrogen removal, during which excess nitrogen (in the form of $\mathrm{NH}_{4}{ }^{+}, \mathrm{NO}_{3}{ }^{-}$and $\mathrm{NO}_{2}{ }^{-}$) is converted into $\mathrm{N}_{2}$ gas and released into the atmosphere. It is performed by microbial communities at and below the sediment surface and represents a significant sink for nitrogen in coastal waters. Most importantly, it is one of the few natural processes capable of removing nitrogen from coastal waters and counteracting eutrophication.

Many attempts have been made to measure denitrification (for reviews see Seitzinger 1988 and Cornwell et al. 1999). At present, denitrification is primarily measured using 2 techniques: in situ benthic chambers and laboratory incubations of sediment cores. Benthic chambers (hereafter referred to as 'chambers') are enclosures that are pushed into the sediment to enclose overlying water in direct contact with the sediment surface. By isolating water and sediment, chambers can be used to determine $\mathrm{NH}_{4}{ }^{+}, \mathrm{NO}_{3}{ }^{-}, \mathrm{NO}_{2}{ }^{-}$and $\mathrm{N}_{2}$ fluxes between the sediment and water interface, through the measurement of concentration changes over time in the enclosed body of water. With this information, estimates of denitrification can be made. The incubation of sediment cores (hereafter referred to as 'cores') uses the same principles for measuring de- 
nitrification but is performed in the laboratory with the potential for increased replication at much lower cost compared to chambers. Cores are samples of intact sediment that are collected in situ and brought back to the laboratory for measurement of e.g. denitrification. The aim of core sampling is to create a laboratory system that simulates in situ conditions.

The use of cores for the measurement of denitrification has certain limitations (Carpenter 1996, Schindler 1998, Ahn \& Mitsch 2002). The most commonly used core cylinders are much smaller than the most commonly used chambers. Consequently, core cylinders generally sample a smaller area than chambers do, such that many replicates are required to sufficiently sample natural spatial variability and obtain a reliable estimate of denitrification. Furthermore, because of their smaller size, core cylinders are more likely to physically exclude large macrofauna that may be important to denitrification. Bioirrigation and bioturbation by macrofauna can enhance denitrification considerably (e.g. Chartarpaul et al. 1980, Sayama \& Kurihara 1983, Kristensen et al. 1991, De Roach et al. 2002). Therefore, depending on the size of the core, the impacts of macrofauna may fail to be incorporated, leading to misleading estimates of denitrification. In addition, sediments are inevitably disturbed (to a greater or lesser degree) by core collection, transportation and handling (Glud et al. 1995, Nielsen \& Glud 1996, Violler et al. 2003). This may lead to chemical, physical or biological alterations of the sediments, which may confound the extrapolation of results to in situ conditions. For example, sediment structure may be disrupted, leading to changes in the activity of bacteria and macrofauna.

Chambers overcome many of the problems associated with cores. They generally cover a larger area of sediment in comparison with cores, smoothing out any small-scale spatial variability that otherwise requires the collection of multiple cores (Glud \& Blackburn 2002). Also, because they are generally larger in size, they are more likely to sample and incorporate the effects of large macrofauna in the sediment that may be excluded by cores. Furthermore, since chambers are deployed in situ, they are less likely to interfere with the natural conditions or processes that might otherwise be affected when cores are brought back to the laboratory. The major limitation of chambers is the number of replicates that can be obtained, due to the cost of construction and deployment (Odum 1984). Chambers can be automated or manual: manual chambers are relatively inexpensive to construct but involve high field costs due to the need for diver deployment; automated chambers, on the other hand, can be deployed from the surface but are expensive to construct. Despite their cost, chambers are widely considered to be the best available technique for measuring denitrification (Berelson \& Hammond 1986, Berelson et al. 1998, Heggie et al. 1999, Nicholson et al. 1999).

Despite the widespread past and current use of cores and chambers for measurement of sediment denitrification (Viollier et al. 2003), and the importance of management decisions based on data obtained from them, the comparability of these 2 techniques is poorly documented. Two studies that compared cores and chambers for measuring denitrification reported conflicting results. Parallel measurements from chambers and cores in the Aarus Bight, Denmark, showed similar rates of denitrification for both methods (Nielsen \& Glud 1996), whereas studies in Arctic Norway (Svalbard) found that denitrification and flux rates in cores were markedly lower than in chambers (Glud et al. 1998). Both studies suspected differences may be due to the exclusion of macrofauna and disturbance of sediment in cores.

We aimed to: (1) compare flux and denitrification efficiency measurements in cores and chambers, (2) determine whether differences in macrofaunal abundances can account for differences in flux measurements in cores and chambers, and (3) determine whether disturbance during collection and transportation of cores to the laboratory can account for different flux measurements in cores and chambers.

\section{MATERIALS AND METHODS}

Study sites. This study was conducted in Port Phillip Bay, Victoria, Australia. Nutrients are a central part of Port Phillip Bay's Environmental Management Plan (NRE 2003). Port Phillip Bay is a shallow semi-enclosed temperate marine embayment $\left(1930 \mathrm{~km}^{2}\right)$ with minimal tidal flushing. Water exchange with Bass Strait is limited by extensive sand banks near the entrance. Consequently, there is minimal loss of nitrogen to Bass Strait and so much of the nitrogen must be removed by denitrification (Hunter 1992).

Port Phillip Bay is bordered by urban and industrial developments and supports Melbourne (population $\sim 3$ million), Australia's second largest metropolitan area. It receives an annual load of approximately 7000 t $\mathrm{N} \mathrm{yr}^{-1}$ (Murray \& Parslow 1999) from 2 main point sources, the Western Treatment Plant and the Yarra River. Denitrification is estimated to remove $>70 \%$ of this nitrogen input (Parslow \& Murray 1999). Modelling of Port Phillip Bay predicts that a substantial decline in denitrification efficiency would lead to eutrophication which would be very difficult to reverse (Murray \& Parslow 1999). Furthermore, the Bay has been invaded by a number of species (e.g. Sabella 
spallanzanii, Asterias amurensis) in recent years (Keough \& Ross 1999, Hewitt et al. 2004) which have the potential to alter denitrification (Murray \& Parslow 1999).

Two sites were chosen for this study; Clifton Springs $\left(38^{\circ} 08^{\prime} \mathrm{S}, 144^{\circ} 32^{\prime} \mathrm{E}\right)$ and Williamstown $\left(37^{\circ} 52^{\prime} \mathrm{S}, 144^{\circ} 53^{\prime} \mathrm{E}\right)$. These sites were chosen because they represent two of the common sediment types thought to be important for denitrification in Port Phillip Bay (Nicholson et al. 1996). All sampling was conducted over unvegetated soft sediment at a depth of $\sim 8 \mathrm{~m}$.

Sampling apparatus. Chambers consisted of a clear polycarbonate cylinder (length $40 \mathrm{~cm}$, inner diameter $29 \mathrm{~cm}$ ) with a closed and open end. The open end was pushed into the sediment to a depth of $\sim 10 \mathrm{~cm}$. This left an enclosed body of overlying 'headspace' water with a height of $\sim 30 \mathrm{~cm}$ and a volume of $\sim 20 \mathrm{l}$. The closed end contained a number of important features including: (1) a sealable sampling tube, (2) pressure/water compensating tube, (3) pulsed dissolved oxygen (DO) probe, and (4) a battery-powered stirring paddle that simulated water currents and prevented water within the chamber becoming stagnant. The DO probe was connected to a data logger programmed to read DO every $10 \mathrm{~min}$. This particular chamber design has been used previously (e.g. Nicholson et al. 1996, 1999).

Core cylinders consisted of a clear Perspex cylinder (length $50 \mathrm{~cm}$, inner diameter $11 \mathrm{~cm}$ ) that was open at both ends. The core cylinders were pushed into the sediment to a depth of $\sim 40 \mathrm{~cm}$. This left a headspace water height of $\sim 10 \mathrm{~cm}$ which equated to a volume of $\sim 1$ 1. Core cylinders had the same important features as chambers (i.e. a sampling tube, pressure compensating tube, DO probe, and stirring paddle). As with chambers, these were placed on the closed end (which for core cylinders were removable). The shear velocity generated by the stirring paddle was $0.34 \mathrm{~cm} \mathrm{~s}^{-1}$ in core cylinders and $0.87 \mathrm{~cm} \mathrm{~s}^{-1}$ in chambers.

Sampling methods. Cores vs. chambers - flux measurements: The core-chamber comparison was conducted at Clifton Springs during March 2004 and Williamstown during May 2004. At each site, 5 plots $(1 \times 1 \mathrm{~m})$ were marked out haphazardly using SCUBA. Chambers were then pushed into the sediment in each plot by divers and allowed to equilibrate for $0.5 \mathrm{~h}$ to allow any sediment that was stirred up during deployment to settle. Duplicate $40 \mathrm{ml}$ water samples were then taken from each chamber. After $\sim 20 \mathrm{~h}$, a second set of water samples was taken. As a control, ambient water samples were taken at the start and end, and DO levels were measured from bottom water outside the chambers throughout the deployment.

Cores were taken from sediments within $50 \mathrm{~cm}$ of the chambers. Divers collected cores by pushing core cylinders into the sediment. While each cylinder was in the sediment, divers placed a bung in the upper end of the cylinder to create suction while cores were carefully lifted out of the sediment. Once this had been done, a second bung was placed in the lower end of the core cylinder. Cores were maintained upright to minimise sediment disturbance. To keep cores at ambient water temperature during transportation, ice was added to seawater-filled bins as necessary. Field water was collected in sterilised plastic containers for replacement of core headspace water in the laboratory.

In the laboratory, bungs were removed from the upper ends of the cylinders, and the cores (in their cylinders) were stored in a large temperaturecontrolled holding tank that had aerated field water flowing through it. Nylon mesh $(300 \mu \mathrm{m})$ was placed over the upper ends of the core cylinders while in the holding tank, to prevent infauna from swimming out of the core cylinders. Cores remained in the holding tank for a minimum of $24 \mathrm{~h}$ before being incubated. This allowed infauna within the cores to re-adjust from any disturbance they may have encountered during the collection, transportation and handling process.

Prior to incubation, ends were re-attached to each core cylinder and the pressure/water compensating tubes were connected to a reservoir containing field water at in situ DO levels. The headspace water was replaced with fresh field water and duplicate $40 \mathrm{ml}$ water samples were taken by syringe at the start of incubation. A second set of samples were taken $45 \mathrm{~h}$ later, once DO levels had dropped to similar levels as chambers ( $50 \%$ saturation). As a control, water samples were taken and DO levels were measured from the field water reservoir. These samples were compared to ambient water samples taken in the field to ensure that cores were incubated under similar conditions as chambers.

Cores vs. chambers-macrofauna: To test whether macrofaunal abundances differed between cores and chambers, the top $10 \mathrm{~cm}$ of sediment from cores and chambers was collected for macrofauna immediately following incubation. Macrofauna were sampled from chambers using a diver-operated suction sampler. The suction sampler drew sediment and the associated macrofauna up into a self-sieving mesh bag (1 mm mesh size). Suction was derived from a petrol-powered water pump aboard a boat positioned directly above the study site. The sampling area was defined by pushing a cylinder into the sediment over the area where the chamber had been. Macrofauna were collected from cores by sieving the top $10 \mathrm{~cm}$ of sediment through a $1 \mathrm{~mm}$ sieve. All macrofauna were stained with $0.1 \%$ Rose Bengal, preserved in $70 \%$ ethanol and then sorted, counted and identified to family level or further using a dissecting microscope. 
Cores vs. chambers - disturbance: Clear differences in fluxes were found between cores and chambers. To test the hypothesis that disturbance of cores during collection, transportation and handling explains the different flux results, we deployed core cylinders in the field and compared them to cores in the laboratory. To do this we modified the core cylinders so that they could be deployed in the field (the stirrer mechanism was encased in a waterproof housing and the DO probe and the sampling and pressure/water compensating tubes were repositioned). Since the new core cylinders were a slightly different design from the old ones, we also made a comparison between the new and old design in the laboratory. The experiment consisted of 6 replicates of 4 treatments: (1) chambers deployed in the field, (2) new core cylinders deployed in the field, (3) new core cylinders incubated in the laboratory, (4) old core cylinders incubated in the laboratory. This experiment was conducted during August and September 2004 at Williamstown $\left(37^{\circ} 52^{\prime} \mathrm{S}\right.$, $\left.144^{\circ} 52^{\prime} \mathrm{E}\right)$.

The following predictions were made: (1) if the cause of lower $\mathrm{DO}, \mathrm{NO}_{3}{ }^{-}$and $\mathrm{NO}_{2}{ }^{-}$fluxes is the disturbance of cores during collection and transportation, then measurements of these fluxes should be similar in cores and chambers in the field; (2) if disturbance during collection and transportation of cores was not the cause of differences between cores and chamber flux measurements, then cores in the field should give the same measurements as cores in the laboratory; (3) if the new-design core cylinders did not alter flux or denitrification efficiency measurements, then they should give the same measurements as the old-design core cylinders.

All details of this experiment were carried out as described previously except all water samples were taken after $20 \mathrm{~h}$ and single samples were taken rather than duplicate samples. Duplicate samples taken in the first experiment generally did not improve estimates, so single samples were taken to reduce costs.

Analysis of water samples. Water samples were analysed for $\mathrm{N}_{2}$ and dissolved inorganic nitrogen (DIN: $\mathrm{NH}_{4}{ }^{+}, \mathrm{NO}_{2}{ }^{-}$and $\mathrm{NO}_{3}{ }^{-}$). For $\mathrm{N}_{2}$ analysis, samples were placed in gas-tight glass vials, and $20 \mu \mathrm{l}$ of $\mathrm{HgCl}_{2}$ was added to each (to prevent microbial growth) before the vials were plugged and stored-submerged, at in situ temperature-until analysis. $\mathrm{N}_{2}$ levels were determined from changes in the $\mathrm{N}_{2}$ : Ar ratios $( \pm 0.05 \%)$ measured on a membrane inlet mass spectrometer (MIMS) using the method and instrumentation of Kana et al. (1994). For analysis of DIN, samples were filtered $(0.45 \mu \mathrm{m})$ and stored frozen in brown high density polyethylene bottles. DIN analysis was carried out by modifications of standard segmented-flow colorimetry methods (Anonymous 1972, 1973), using methods adapted for detection of low levels in seawater. Samples were analysed in duplicate. If duplicates differed by more than twice the detection limit, the analysis was repeated.

Calculations. Net flux, the difference between 2 unidirectional fluxes, will hereafter be referred to as 'flux'. Flux was measured in units of $\mu \mathrm{mol} \mathrm{m}{ }^{-2} \mathrm{~d}^{-1}$ using the following:

$$
\text { Flux }=\frac{\Delta \mathrm{C}}{\Delta \mathrm{T}} \times \frac{\mathrm{V}}{\mathrm{A}}
$$

where $\Delta \mathrm{C}$ is the change in concentration of solute $\left(\mu \mathrm{mol} \mathrm{l}{ }^{-1}\right), \Delta \mathrm{T}$ is the duration of incubation $(\mathrm{d}), \mathrm{V}$ is the volume of water enclosed (1), and A is the seafloor area $\left(\mathrm{m}^{2}\right)$.

Denitrification efficiency (DE, \%) was defined as the proportion of nitrogen fluxed into the water column as $\mathrm{N}_{2}$ compared with the total DIN fluxed into the water column and was calculated from the following:

$$
\mathrm{DE}=\frac{\mathrm{N}_{2}}{\mathrm{~N}_{2}+\mathrm{DIN}} \times 100
$$

where $\mathrm{N}_{2}$ is the number of moles of nitrogen fluxed into the water column as $\mathrm{N}_{2}$, and DIN is the number of moles of DIN fluxed into the water column.

Statistical analysis. Fluxes, denitrification efficiency measurements, and macrofaunal densities in cores and chambers were compared using 2-sample $t$-tests and variance was compared by $F$-tests. Macrofaunal groups were analysed if they occurred in $\geq 80 \%$ of either core or chamber replicates from Williamstown. Because overall densities were lower at Clifton Springs, macrofauna were analysed if they were found in $\geq 60 \%$ of replicates. Macrofaunal groups that did not meet these cut offs, but have previously been established as important bioirrigators or bioturbators (e.g. callianasid shrimp) were also analysed. Macrofaunal groups not meeting either of these criteria were combined into higher taxonomic groups for analysis. Pearson correlation analyses were used to look for correlations between nutrient fluxes and macrofauna densities.

In the disturbance experiment, 1-way ANOVA and planned comparisons were made among treatments for all flux and denitrification efficiency measurements. The 4 treatments were: chambers in the field (C), new core cylinders in the field (NF), new core cylinders in the laboratory (NL), and old core cylinders in the laboratory (OL). Planned comparisons were first made between OL and NL to determine whether the 2 designs gave different results. When this was not significant, results from all laboratory cores ([OL+NL]/2) were combined and compared with NF to test the effects of deploying core cylinders in the field compared to in the laboratory. When no significant differ- 
ences were observed between laboratory cores and field cores, all cores were combined $([\mathrm{OL}+\mathrm{NL}+\mathrm{NF}] / 3)$ and compared with C. Statistical tests were accepted as significant at $\mathrm{p}<0.05$. All data presented are untransformed as transforming did not improve normality.

\section{RESULTS}

\section{Cores vs. chambers - fluxes}

The rate of DO depletion was significantly higher in chambers than cores (Fig. 1, Table 1). In chambers, DO levels dropped $\sim 6$ times faster than in cores. This pattern was consistent at both sites. $\mathrm{N}_{2}$ fluxes were similar in cores and chambers (Fig. 1, Table 1). On the whole, $\mathrm{N}_{2}$ flux was directed out of the sediment and into the water column in chambers and cores at both sites. Fluxes of total DIN and $\mathrm{NH}_{4}{ }^{+}$were similar in cores and chambers at both sites (Fig. 1, Table 1), but fluxes of $\mathrm{NO}_{3}{ }^{-}$and $\mathrm{NO}_{2}{ }^{-}$weren't always comparable. $\mathrm{NO}_{3}{ }^{-}$and $\mathrm{NO}_{2}{ }^{-}$fluxes were significantly lower in cores than chambers at both sites (Fig. 1, Table 1). $\mathrm{NO}_{3}{ }^{-}$flux was mostly directed into the sediments in cores and out of the sediment in chambers (Fig. 1). $\mathrm{NO}_{2}{ }^{-}$was mostly fluxed out of the sediment in chambers at both sites (Fig. 1). $\mathrm{NO}_{2}^{-}$fluxes were negligible in cores. In general, the fluxes of $\mathrm{N}_{2}, \mathrm{NH}_{4}{ }^{+}, \mathrm{NO}_{3}^{-}$and $\mathrm{NO}_{2}{ }^{-}$were greater at Williamstown than Clifton Springs. Given that core cylinders sample a smaller area than chambers, we predicted that flux measurements would be more variable in cores. However, there were more instances where flux measurements were significantly more variable in chambers than cores (Table 1), although no consistent pattern was observed.

There were no significant differences in denitrification efficiency in cores and chambers at either site (Fig. 2, Clifton Springs: df $=8, t=-1.975, \mathrm{p}=0.084$, Williamstown: $\mathrm{df}=8, t=-0.929, \mathrm{p}=0.380$ ).

\section{Cores vs. chambers - macrofauna}

At Clifton Springs the mean abundance of individuals was $1845 \mathrm{~m}^{-2}$. The dominant groups were crustaceans $(63 \%)$ and bivalves $(8 \%)$. There were no significant differences in the mean densities of macrofauna in cores and chambers (data not shown), but

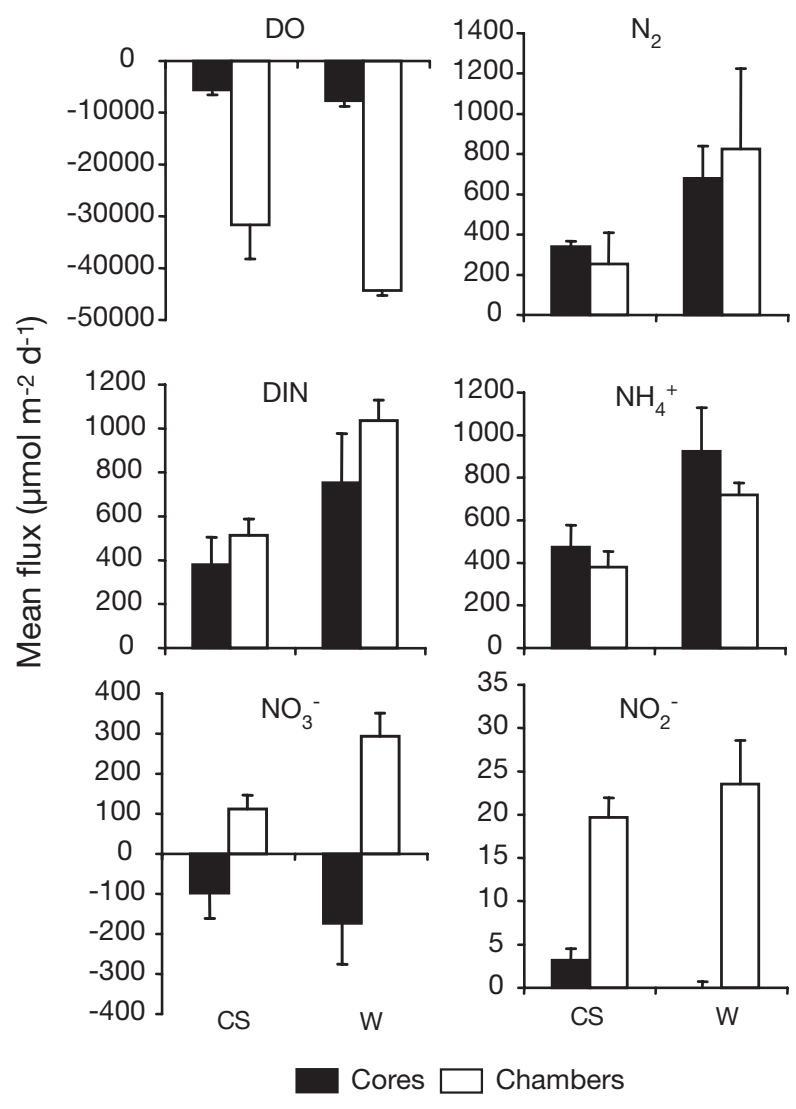

Fig. 1. Mean fluxes $( \pm \mathrm{SE})$ of dissolved oxygen (DO), $\mathrm{N}_{2}$ dissolved inorganic nitrogen (DIN), $\mathrm{NH}_{4}{ }^{+}, \mathrm{NO}_{3}{ }^{-}$, and $\mathrm{NO}_{2}{ }^{-}$ in cores and chambers from Clifton Springs (CS) and Williamstown (W). Positive flux values indicate net fluxes out of the sediment and into the water column. Negative flux values indicate net fluxes into the sediment from the water column

Table 1. Comparison of mean $(2$-sample $t$-test, $\mathrm{df}=8)$ and variance $(2$-tailed $F$-test, $\mathrm{df}=4,4)$ for flux measurements $\left(\mu m o l \mathrm{~m}^{-2} \mathrm{~d}^{-1}\right)$ from cores and chambers from Clifton Springs and Williamstown. The F-test was calculated as core/chamber for each value. Bold: $\mathrm{p}<0.05$

\begin{tabular}{|c|c|c|c|c|c|c|c|c|}
\hline \multirow{3}{*}{ Nutrient } & \multicolumn{4}{|c|}{ Clifton Springs } & \multicolumn{4}{|c|}{ - Williamstown } \\
\hline & \multicolumn{2}{|c|}{ Mean } & \multicolumn{2}{|c|}{ Variance } & \multicolumn{2}{|c|}{ Mean } & \multicolumn{2}{|c|}{ Variance } \\
\hline & $t$ & $\mathrm{p}$ & F-ratio & $\mathrm{p}$ & $t$ & $\mathrm{p}$ & F-ratio & $\mathrm{p}$ \\
\hline DO & -3.96 & 0.005 & 50.543 & 0.001 & -24.99 & $<0.001$ & 0.701 & 0.369 \\
\hline $\mathrm{N}_{2}$ & -0.56 & 0.591 & 34.193 & 0.002 & 0.34 & 0.744 & 6.134 & 0.053 \\
\hline DIN & 0.94 & 0.373 & 0.339 & 0.160 & 1.17 & 0.277 & 0.169 & 0.057 \\
\hline $\mathrm{NH}_{4}{ }^{+}$ & -0.71 & 0.501 & 0.503 & 0.261 & -0.97 & 0.362 & 0.075 & 0.014 \\
\hline $\mathrm{NO}_{3}^{-}$ & 2.94 & 0.019 & 0.284 & 0.125 & 3.97 & 0.004 & 0.326 & 0.152 \\
\hline $\mathrm{NO}_{2}^{-}$ & 6.32 & $<0.001$ & 2.630 & 0.186 & 4.62 & 0.002 & 0.001 & $<0.001$ \\
\hline
\end{tabular}




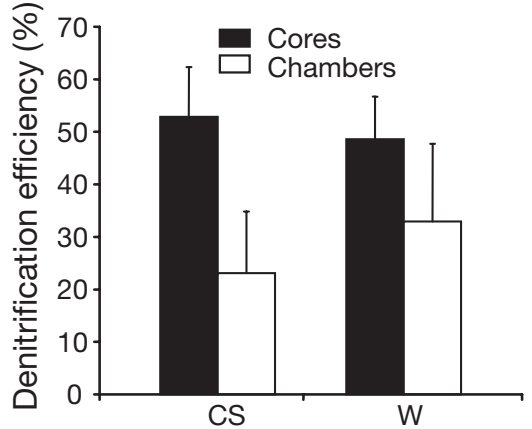

Fig. 2. Denitrification efficiency (mean \pm SE) from cores and chambers at Clifton Springs (CS) and Williamstown (W)

variability was significantly higher in cores than chambers for most groups (Fig. 3). A number of less common taxa (crabs, heart urchins and brittle stars) were collected in chambers but not cores.

At Williamstown the mean abundance of individuals was $3243 \mathrm{~m}^{-2}$. The dominant groups were crustaceans (45\%), polychaetes $(31 \%)$, and bivalves (14\%). No significant differences were observed in the mean densities of macrofauna in cores and chambers (data not shown), and variance in the mean density sampled by cores was significantly higher than chambers for most groups (Fig. 4). Some of the less common taxa (gastropods, cumaceans, and the bivalve Fulvia tenuicostata) were present in chambers but not cores.

We looked for correlations between macrofaunal densities and fluxes. A number of macrofaunal groups were correlated with fluxes in cores and chambers (data not shown), however, no obvious relationships were observed, and the number of significant results $(<5 \%)$ was no more than that which would be expected by chance.

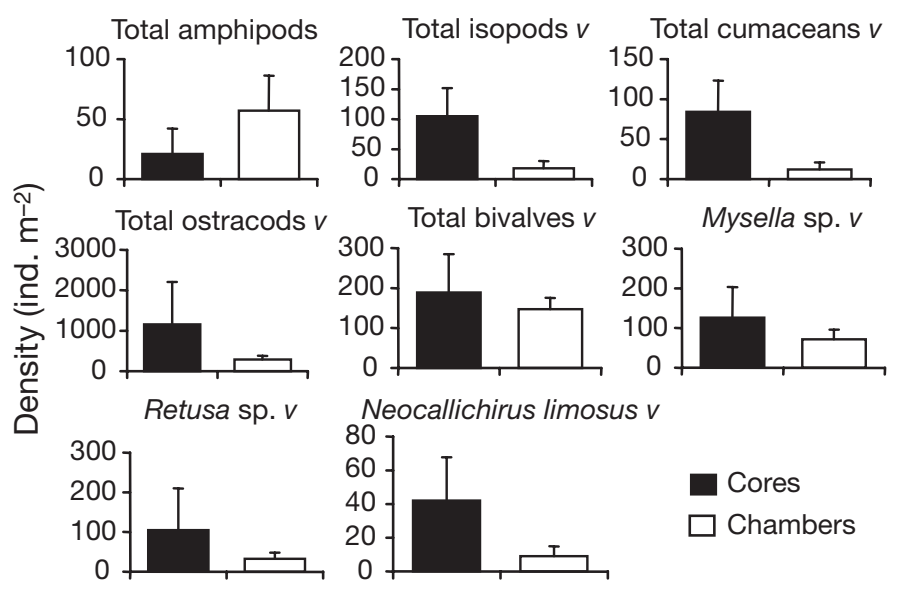

Fig. 3. Density (mean $\pm \mathrm{SE}$ ) of macrofaunal groups in cores and chambers from Clifton Springs. $v$ : significant differences in variance of macrofaunal densities between cores and chambers

\section{Cores vs. chambers - disturbance}

No significant differences were observed between old and new core cylinders in the laboratory (Table 2, Figs. $5 \& 6$ ), suggesting that modifications to old core cylinders had no effect on fluxes or denitrification efficiency. There were no significant differences in flux or denitrification efficiency measurements between cores in the laboratory and field (Table 2, Figs. 5 \& 6). Therefore, disturbance during collection, transportation and handling of laboratory cores could not account for differences in flux measurements in cores and chambers. Fluxes of $\mathrm{DO}, \mathrm{N}_{2}, \mathrm{DIN}, \mathrm{NH}_{4}{ }^{+}$, and $\mathrm{NO}_{3}{ }^{-}$were significantly higher in chambers than in cores (Table 2, Fig. 5). Measurements of $\mathrm{NO}_{2}^{-}$flux and denitrification efficiency were not significantly different in cores and chambers (Table 2, Figs. 5 \& 6).

\section{DISCUSSION}

Denitrification is measured using cores or chambers under the assumption that they give comparable measurements. This is an important assumption as it concerns our ability to accurately measure how much nitrogen is being removed from a system and affects whether we can combine studies to produce broader syntheses. We found that estimates of denitrification efficiency were not significantly different between cores and chambers at 2 sites in Port Phillip Bay. Furthermore, when we compared laboratory cores and chambers in the disturbance experiment there was no significant difference. Even after combining the core and chamber data from all of these experiments, there were still no significant differences between core and chamber measurements (Table 3 ). It should be noted, however, that even this analysis had relatively low power $(47 \%)$ to detect a $20 \%$ change, which would be considered a substantial change in denitrification efficiency. Although overall denitrification was not significantly different, there were substantial differences in individual fluxes. The flux patterns offered strong evidence that denitrification was not always taking place via the same pathways in cores and chambers.

Denitrification can be coupled or uncoupled (Herbert 1999). During coupled denitrification, denitrifying bacteria are supplied with $\mathrm{NO}_{3}{ }^{-}$by nitrifying bacteria in the oxic layers of the sediment. Alternatively, denitrifying bacteria can obtain $\mathrm{NO}_{3}{ }^{-}$from the water column during uncoupled denitrification. In chambers, denitrification appeared to be coupled as indicated by net production and flux of $\mathrm{NO}_{2}^{-}$and $\mathrm{NO}_{3}^{-}$out of the sediment and into the water column. In cores, net fluxes of $\mathrm{NO}_{3}{ }^{-}$into the sediment and negligible overall $\mathrm{NO}_{2}^{-}$production suggested that sedimentary nitrifica- 

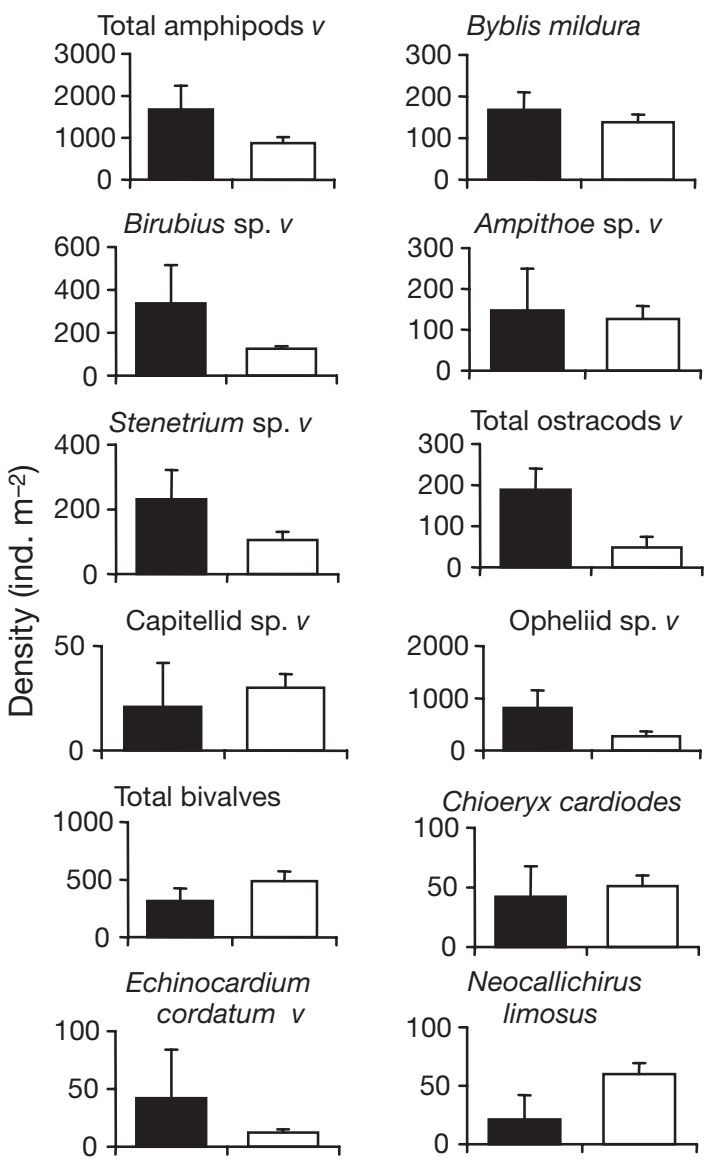

Fig. 4. Density (mean $\pm \mathrm{SE}$ ) of macrofaunal groups in cores and chambers from Williamstown. $v$ : significant differences in variance of macrofaunal densities between cores and chambers

tion was not meeting the requirements of denitrification and consequently, the relative importance of uncoupled denitrification in cores was greater.

We propose 2 scenarios to explain the different pathways in cores and chambers. In chambers, large amounts of oxygen penetrated the sediment, creating a broad oxic zone for nitrification to take place (Blackburn \& Blackburn 1993). Nitrifying bacteria produced $\mathrm{NO}_{3}{ }^{-}$, which was subsequently denitrified or fluxed back into the water column (Jenkins \& Kemp 1984). The broad oxic zone had 2 important consequences for denitrification in chambers. First, it increased the transport distance for $\mathrm{NO}_{3}{ }^{-}$from the water column to reach the anoxic zone (Cook et al. 2004) so that denitrifying bacteria relied predominantly on $\mathrm{NO}_{3}{ }^{-}$supply through nitrification (i.e. coupled denitrification). Second, the broad oxic zone decreased the volume

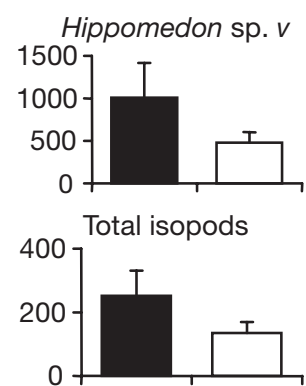

Total polychaetes
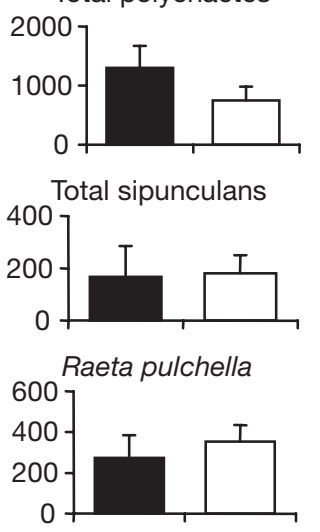

Cores

Chambers

of sediment habitable by denitrifying bacteria (Herbert 1999) and consequently, there were less denitrifying bacteria and therefore less demand for $\mathrm{NO}_{3}{ }^{-}$from nitrification. A reduced demand for denitrification is consistent with more $\mathrm{NO}_{3}{ }^{-}$fluxed out of the sediment, as was observed.

In cores, small amounts of oxygen penetrated the sediments compared to chambers. This narrowed the oxic zone and reduced the sediment volume available for sedimentary nitrification to take place (Cook et al. 2004), which is why only small amounts of $\mathrm{NO}_{2}^{-}$and $\mathrm{NO}_{3}{ }^{-}$were produced. Thus, the potential for coupled nitrification-denitrification was reduced and denitrifying bacteria relied to a greater degree on water column $\mathrm{NO}_{3}{ }^{-}$as a substrate for denitrification (i.e. uncoupled denitrification). Due to the lack of $\mathrm{NO}_{3}{ }^{-}$production in sediments, a concentration gradient drove $\mathrm{NO}_{3}{ }^{-}$from the water column into the sediment (Santschi et al. 1990) explaining why there were net fluxes of $\mathrm{NO}_{3}{ }^{-}$from the water column into the sediment. A lack of oxygen penetration into the sediment caused the oxic zone to narrow, so that the transport distance for $\mathrm{NO}_{3}{ }^{-}$to reach the anoxic sediment decreased, facilitating uncoupled denitrification in cores.

While we can only suggest a mechanism, the data strongly suggest that the relative importance of uncoupled and coupled denitrification is different in cores and chambers, and therefore cores and chambers are not directly comparable. If the cause of difference can

Table 2. Results of a 1-way ANOVA and planned comparisons for differences in fluxes $\left(\mu \mathrm{mol} \mathrm{m} \mathrm{m}^{-2} \mathrm{~d}^{-1}\right)$ and denitrification efficiency $(\%)$ at Williamstown. The 4 treatments were: chambers in the field (C), new core cylinders in the field (NF), new core cylinders in the laboratory (NL), and old core cylinders in the laboratory (OL). Bold: $\mathrm{p}<0.05$

\begin{tabular}{|c|c|c|c|c|c|c|}
\hline \multirow[t]{2}{*}{ Nutrient } & \multicolumn{3}{|c|}{ ANOVA } & \multicolumn{3}{|c|}{ Planned comparisons } \\
\hline & $\mathrm{df}$ & MS & $\mathrm{p}$ & OL vs. NL & NL vs. NF & C vs. Cores \\
\hline DO & 20 & 3.78 & 0.000 & 0.497 & 0.788 & 0.000 \\
\hline $\mathrm{N}_{2}$ & 19 & 10650.06 & 0.139 & 0.797 & 0.932 & 0.023 \\
\hline DIN & 20 & 234344.99 & 0.004 & 0.413 & 0.766 & 0.000 \\
\hline $\mathrm{NH}_{4}{ }^{+}$ & 20 & 218408.56 & 0.007 & 0.398 & 0.645 & 0.001 \\
\hline $\mathrm{NO}_{3}^{-}$ & 20 & 2091.44 & 0.005 & 0.996 & 0.242 & 0.001 \\
\hline $\mathrm{NO}_{2}^{-}$ & 20 & 118.01 & 0.128 & 0.906 & 0.124 & 0.066 \\
\hline $\begin{array}{l}\text { Denitrifica- } \\
\text { tion efficiency }\end{array}$ & 19 & 1040.56 & 0.535 & 0.687 & 0.277 & 0.373 \\
\hline
\end{tabular}



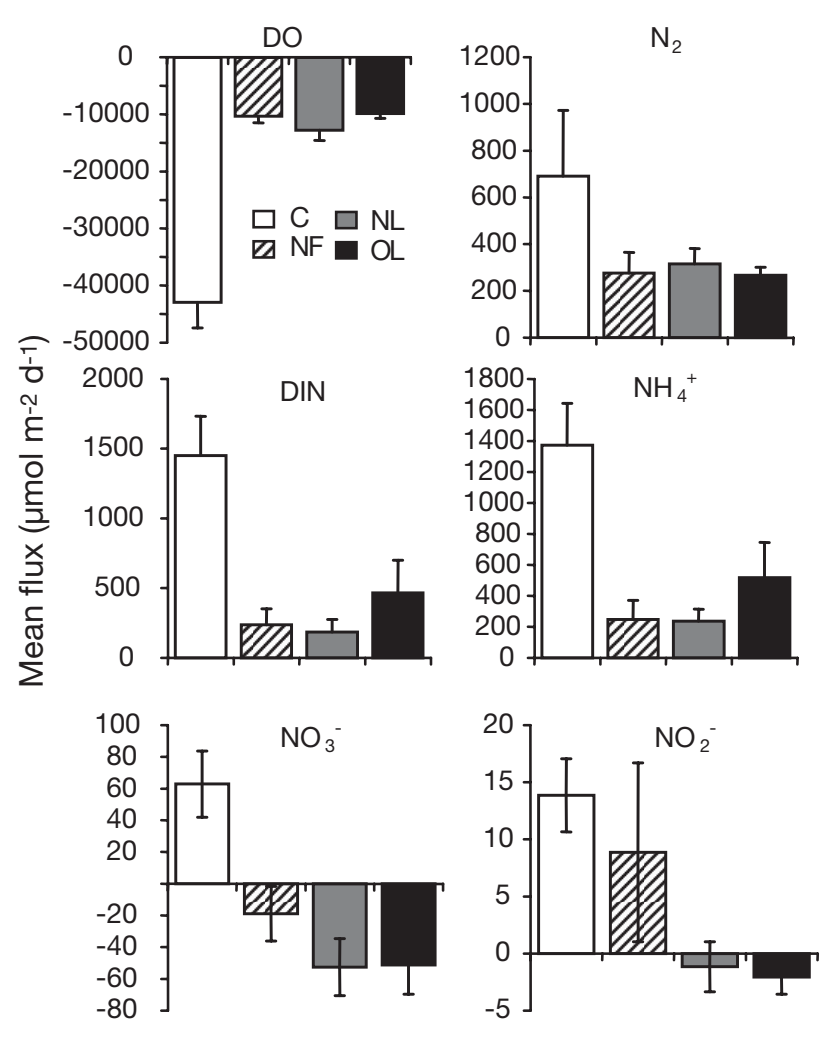

Fig. 5. Mean fluxes $( \pm \mathrm{SE})$ of dissolved oxygen (DO), $\mathrm{N}_{2}$, dissolved inorganic nitrogen (DIN), $\mathrm{NH}_{4}{ }^{+}, \mathrm{NO}_{3}{ }^{-}$, and $\mathrm{NO}_{2}{ }^{-}$in chambers (C), new core cylinders in the field (NF), new core cylinders in the laboratory (NL), and old core cylinders in the laboratory (OL). Positive fluxes indicate that the solute is being fluxed out of the sediment and negative fluxes indicate that the solute is being fluxed into the sediment

be determined, then it is possible that cores could be modified to give comparable measurements to chambers leading to substantial cost savings. The next aim of our study was to attempt to determine the cause of differences between cores and chambers.

Oxygen penetration depth was considered an important factor leading to differences in core and chamber flux measurements. We proposed that differences in oxygen penetration could be explained by differences in the levels of fauna-mediated oxygen consumption (FOU). Unlike diffusive $\mathrm{O}_{2}$ uptake, which is inversely proportional to oxygen penetration depth, FOU comprises $\mathrm{O}_{2}$ consumption associated with ventilation of macrofauna burrows and can lead to an increase in oxygen penetration depth and a broadening of the oxic zone (Glud et al. 2003). Since core cylinders are more likely to physically exclude large macrofauna because of the small size of the former relative to chambers (Glud \& Blackburn 2002), we compared the densities

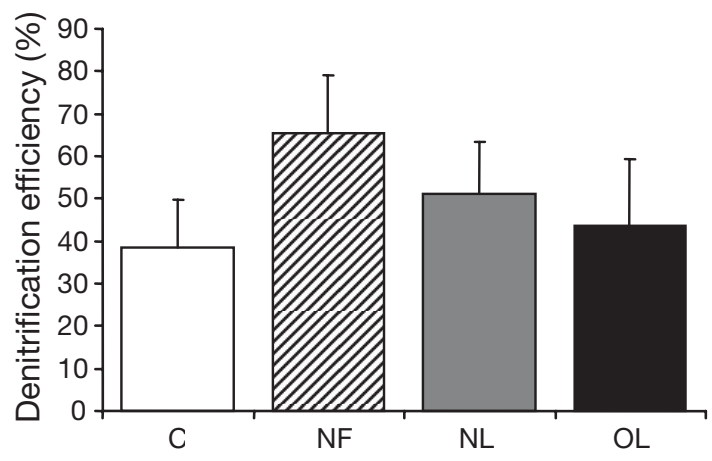

Fig. 6. Denitrification efficiency measurements (mean $\pm \mathrm{SE}$ ) from chambers $(\mathrm{C})$, new core cylinders in the field (NF), new core cylinders in the laboratory (NL), and old core cylinders in the laboratory (OL)

of macrofauna sampled by core cylinders and chambers to determine whether physical exclusion could account for differences between core and chamber flux measurements. We found that core cylinders failed to sample certain macrofaunal groups at our study sites. Two of these groups, brittle stars and heart urchins, have been shown to influence nutrient fluxes. The heart urchin Echinocardium australe influences fluxes of oxygen, $\mathrm{NO}_{3}{ }^{-}$and $\mathrm{NH}_{4}{ }^{+}$at densities of 70 ind. $\mathrm{m}^{-2}$ (Lohrer 2003) and the brittle star Amphiura filiformis influences fluxes at densities of 1326 ind. $\mathrm{m}^{-2}$ (Vopel et al. 2003). At our study sites, heart urchins and brittle stars were found at densities of 12 and 6 ind. $\mathrm{m}^{-2}$, respectively. Given that the densities of these groups were significantly lower than those reported by Loher (2003) and Vopel et al. (2003) it is difficult to ascertain whether they might have affected fluxes at our sites. However, it does demonstrate that cores may fail to incorporate the effects of taxa that are large and/or present in low densities.

We also tested the hypothesis that insufficient core replicates were taken to adequately sample natural spatial variability and obtain reliable flux estimates. We found no significant difference in the mean densities of macrofauna sampled by core cylinders and chambers at either study site. It is therefore unlikely that differences in the mean densities of macrofauna
Table 3. Results of a 2-way ANOVA for differences in denitrification efficiency measurements using cores and chambers. Experiments and treatments were treated as fixed factors

\begin{tabular}{|lrrrr|}
\hline & df & MS & F-ratio & $\mathrm{p}$ \\
\hline Experiment & 2 & 29.833 & 0.037 & 0.963 \\
Treatment (cores vs. chambers) & 1 & 2185.021 & 2.731 & 0.111 \\
Experiment $\times$ Treatment & 2 & 399.762 & 0.5 & 0.613 \\
Residual & 25 & 800.214 & & \\
& & & & \\
\hline
\end{tabular}


can account for differences in flux estimates. However, as anticipated, density estimates were significantly more variable in cores for most macrofaunal groups.

Disturbance was thought to be another possible cause of differences between cores and chambers. The deployment of chambers in situ involves relatively little disturbance to the sediment being sampled. Chambers are simply inserted over an area of sediment and then incubation begins. Cores on the other hand may undergo large amounts of disturbance as they are collected from the seafloor, brought to the surface, and then transported back to the laboratory. This can lead to a number of forms of disturbance with the potential to introduce physical, chemical or biological changes in cores.

To determine whether disturbance during collection, transportation, and handling could account for difference between cores and chambers, we deployed core cylinders in the field and found that they gave similar measurements as core cylinders in the laboratory. Therefore, these forms of disturbance could not account for differences between cores and chambers. This was an important finding as it allowed us to eliminate a number of potential reasons why cores and chambers differ. For example, we considered the effects of pressure changes as cores are brought to the surface to be a potential cause of difference between cores and chambers. Cores brought to the surface from depths $>20 \mathrm{~m}$ undergo decompression which disturbs biological activity and pore-water chemistry (Jahnke et al. 1989, Glud et al. 1995). As there were no differences between cores we deployed in the field and those we brought to the surface, we were able to discount pressure changes as a source of significant differences between cores and chambers.

Another source of major concern was our ability to simulate in situ conditions, such as light, in the laboratory. We conducted our laboratory incubations using normal room lighting on a day/night cycle. Variation in light could alter photosynthetic patterns of microphytobenthos in the sediments and affect the comparability of cores and chambers. Higher rates of coupled denitrification in light lead to increased nitrification activity due to photosynthetically-mediated increases in oxygen penetration depth (Risgaard-Petersen et al. 1994). However, our disturbance experiment showed that differences in light exposure were unlikely to lead to differences between cores and chambers, since cores in the field did not differ significantly from cores in the laboratory.

Although the possibilities were narrowed, we were unable to determine the exact cause of differences between cores and chambers. However, during the disturbance experiment, we identified another form of disturbance which we believe may be responsible for the differences between cores and chambers. When core cylinders were inserted into the sediment, the sediment inside the cylinders became compressed. This could affect burrowing macrofauna and the bacteria associated with their burrow walls. Core-cylinder insertion can damage macrofauna and cause their burrows to collapse (Herbert 1999, Glud \& Blackburn 2002). Obviously, macrofaunal activity will be affected by this, and their potential effects on denitrification or fluxes modified. Perhaps more important is the damage caused to the bacteria that line their burrow walls. Several studies have observed higher nitrification activity in the sediment lining burrow walls compared to sediment without burrows (Hylleberg \& Henriksen 1980, Henriksen et al. 1983, Kristensen 1985). This is because burrow walls provide aerobic sites for nitrifying bacteria to inhabit which leads to higher nitrification capacity. Compression of sediment could therefore reduce nitrification capacity. The reason that this is more likely to occur in cores than chambers is due to differences between the edge/area ratios of cores and chambers. The ratio of edge to sediment surface area was $0.36 \mathrm{~cm}^{-1}$ in cores compared to $0.14 \mathrm{~cm}^{-1}$ in chambers. This means that a greater proportion of sediment is exposed to edge effects in cores. Another contributor to compression of sediment in cores is the depth of insertion. Core cylinders were inserted into the sediment to a depth of $\sim 40 \mathrm{~cm}$ for comparability with laboratory cores, whereas chambers were only inserted to a depth of $\sim 10 \mathrm{~cm}$. Considerable force was required to insert core cylinders to this depth which would have also contributed to greater sediment compression.

Our compression hypothesis leads to the question of whether core cylinders could be modified to give similar flux estimates to chambers. If the core diameter was increased and depth of insertion was reduced, then we predict that cores would give similar results to chambers. However, such modifications may not be logistically possible. If core cylinder diameter was increased to a similar size as that of chambers, it would be difficult to achieve adequate suction to withdraw the sediment intact. Reducing the depth of core-cylinder insertion would preclude some deeper-burrowing, but potentially important, species. At present there appears to be no resolution to such issues. Further study is required to investigate different core-cylinder designs. The container walls of core cylinders and chambers define the experimental system and help enclose a body of water for measurement of nutrient exchange, but they also create sites for artificial interactions (Chen \& Kemp 2004). The potential artifacts introduced by the enclosure process will always need to be borne in mind.

During the second experiment we found that cores introduce an artifact that could affect their comparability to chambers, and potentially lead to false or mis- 


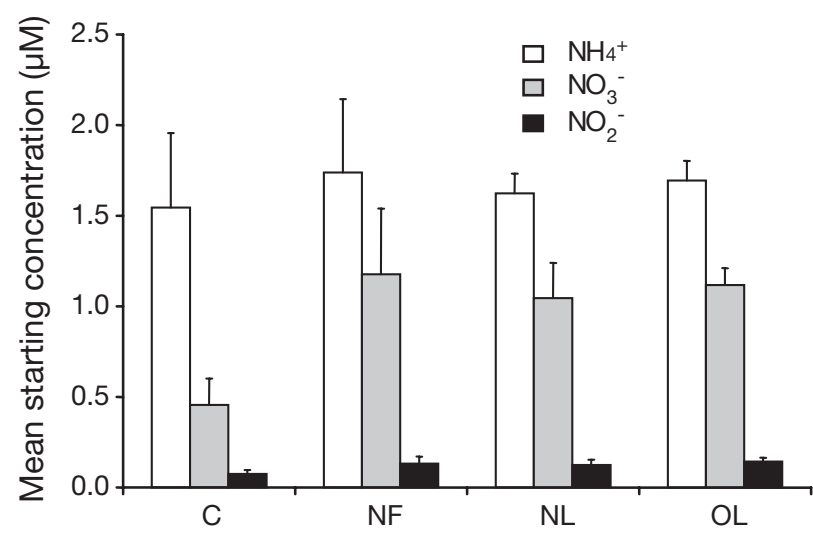

Fig. 7. Mean starting concentrations $( \pm \mathrm{SE})$ of $\mathrm{NH}_{4}{ }^{+}, \mathrm{NO}_{3}{ }^{-}$, and $\mathrm{NO}_{2}{ }^{-}$from chambers in the field $(\mathrm{C})$, new core cylinders in the field (NF), new core cylinders in the laboratory (NL), and old core cylinders in the laboratory (OL)

leading flux and denitrification efficiency measurements. We observed that $\mathrm{NO}_{3}{ }^{-}$levels in the first water samples taken were much higher in cores than chambers (Fig. 7). These higher $\mathrm{NO}_{3}{ }^{-}$levels have the potential to dramatically influence denitrification pathways. A number of studies have shown a direct relationship between water column $\mathrm{NO}_{3}{ }^{-}$concentrations and denitrification rates (Pelegri et al. 1994, Kana et al. 1998). Denitrifying bacteria can rapidly respond to increases in the concentration of $\mathrm{NO}_{3}{ }^{-}$in the water column and thereby shift from coupled to uncoupled denitrification (Kana et al. 1998).

In coastal systems, the main source of $\mathrm{NO}_{3}{ }^{-}$for denitrification comes from nitrification in the sediment rather than from water column $\mathrm{NO}_{3}{ }^{-}$(Seitzinger 1988). This generalisation also applies to Port Phillip Bay where $\mathrm{NO}_{3}{ }^{-}$levels are usually low $(<0.5 \mu \mathrm{M}$; Longmore et al. 1996). However, higher levels of $\mathrm{NO}_{3}{ }^{-}$could lead to a shift from coupled to uncoupled denitrification. This is one potential reason why there appeared to be more uncoupled denitrification taking place in cores.

It is difficult to explain why cores had higher concentrations of $\mathrm{NO}_{3}{ }^{-}$at the time that the first water sample was taken. One possibility is that core-cylinder insertion compressed the sediment and forced $\mathrm{NO}_{3}{ }^{-}$from the sediment out into the overlying water. However this is difficult to explain given that cores remained in a holding tank for $>24 \mathrm{~h}$ after collection, during which time the headspace water was continuously mixed with field water in the holding tank. Furthermore, the field water and headspace water was completely replaced just prior to the incubation. If core compression forced $\mathrm{NO}_{3}{ }^{-}$out of the sediment, we might have also expected $\mathrm{NH}_{4}{ }^{+}$and $\mathrm{NO}_{2}{ }^{-}$to be forced out given their presence in sediment pore-water, yet they were no differences detected in levels of the latter two sub- stances between cores and chambers (Fig. 7). Given that compression is an unlikely cause, it would seem that there was a rapid build up of $\mathrm{NO}_{3}{ }^{-}$levels in cores during the $0.5 \mathrm{~h}$ period before the first water samples were taken. This may have come from a semi-labile pool in the sediments that was released during the $0.5 \mathrm{~h}$ period. Whatever the reason is for higher levels of $\mathrm{NO}_{3}{ }^{-}$, it is apparent that artifacts such as this are inherent problems of using cores of this size.

Cores and chambers are used worldwide to provide information for coastal nutrient management. The effectiveness of management strategies depends on obtaining reliable estimates of nutrient cycling. This study demonstrates that cores and chambers give different estimates and should be used with caution. Our results suggest that the relative importance of different pathways for denitrification varies between cores and chambers. In chambers denitrification appeared closely coupled to sedimentary nitrification, whereas in cores there was greater reliance on uncoupled denitrification. Differences in macrofaunal abundances in cores and chambers and disturbance during collection, transportation and handling of cores could not account for these findings. We suggest that compression of sediment during core cylinder penetration may be responsible for these differences, but further research is required to test this hypothesis.

Acknowledgements. We thank A. O'Brien, J. Ahern, L. Barr, and $M$. Reardon for assistance with collection and processing of samples. An Australian Research Council linkage grant supported this research.

\section{LITERATURE CITED}

Ahn C, Mitsch WJ (2002) Scaling considerations of mesocosm wetlands in simulating large created freshwater marshes. Ecol Eng 18:327-342

Anonymous (1972) Nitrate and nitrite in water and seawater. Industrial Method 158-71W. Technicon Instrument Corp, Tarrytown, NY

Anonymous (1973) Ammonia in water and seawater. Industrial Method 154-71W. Technicon Instrument Corp, Tarrytown, NY

Berelson WM, Hammond DE (1986) The calibration of a new free vehicle benthic flux chamber for use in the deep sea. Deep-Sea Res 33:1439-1454

Berelson WM, Heggie D, Longmore A, Kilgore T, Nicholson G, Skyring G (1998) Benthic nutrient recycling in Port Phillip Bay, Australia. Estuar Coast Shelf Sci 56:917-934

Blackburn TH, Blackburn ND (1993) Rates of microbial processes in sediments. Phil Trans R Soc Lond 344:49-58

Carpenter SR (1996) Microcosm experiments have limited relevance for community and ecosystem ecology. Ecology 77 : $667-680$

Chartarpaul L, Robinson JB, Kaushik NK (1980) Effects of tubificid worms on denitrification and nitrification in stream sediment. Can J Fish Aquat Sci 37:656-663

Chen C, Kemp MW (2004) Periphyton communities in experimental marine ecosystems: scaling the effects of removal from container walls. Mar Ecol Prog Ser 271:27-41 
Cook PLM, Eyre BD, Leeming R, Butler ECV (2004) Benthic fluxes of nitrogen in the tidal reaches of a turbid high nitrate subtropical river. Estuar Coast Shelf Sci 59: 675-685

Cornwell JC, Kemp MW, Kana TM (1999) Denitrification in coastal ecosystems: methods, environmental controls, and ecosystem level controls, a review. Aquat Ecol 33:41-54

De Roach RJ, Rate AW, Knott B, Davies PM (2002) Denitrification activity in sediment surrounding polychaete (Ceratonereis aequisetis) burrows. Mar Freshw Res 53:35-41

Glud RN, Blackburn N (2002) The effects of chamber size on benthic oxygen uptake measurements: a simulation study. Ophelia 56:23-31

Glud RN, Gundersen JK, Revsbech NP, Jørgensen BB, Hüttel $M$ (1995) Calibration and performance of the stirred flux chamber from the benthic lander ELINOR. Deep-Sea Res 42:1029-1042

Glud RN, Holby O, Hoffmann F, Canfield DE (1998) Benthic mineralization and exchange in Artic sediments (Svalbard, Norway). Mar Ecol Prog Ser 173:237-251

Glud RN, Gundersen JK, Roy H, Jørgensen BB (2003) Seasonal dynamics of benthic $\mathrm{O}_{2}$ uptake in a semienclosed bay: importance of diffusion and faunal activity. Limnol Oceanogr 48:1265-1276

Heggie DT, Skyring GW, Orchardo J, Longmore AR, Nicholson GJ, Berelson WM (1999) Denitrification and denitrifying efficiencies in sediments of Port Phillip Bay: direct determinations of biogenic $\mathrm{N}_{2}$ and N-metabolite fluxes with implications for water quality. Mar Freshw Res 50:589-596

Henriksen K, Rasmussen MB, Jensen A (1983) Effect of bioturbation on microbial nitrogen transformations in the sediment and fluxes of ammonium and nitrate to the overlying water. Ecol Bull 35:193-205

Herbert RA (1999) Nitrogen cycling in coastal marine ecosystems. FEMS Microbiol Rev 23:563-590

Hewitt CL, Cambell ML, Thresher RE, Martin RB and 15 others (2004) Introduced and cyptogenic species in Port Phillip Bay, Victoria, Australia. Mar Biol 144:183-202

Hunter JR (1992) Review of physical processes. Port Phillip Bay Environmental Study Technical Report No. 9. CSIRO, Canberra

Hylleberg J, Henriksen K (1980) The central role of bioturbation in sediment mineralization and element recycling. Ophelia 14:113-137

Jahnke RA, Emerson SR, Reimers CE, Schuffert J, Ruttenberg $\mathrm{K}$, Archer D (1989) Benthic recycling of biogenic debris in the eastern tropical Atlantic Ocean. Geochim Cosmochim Acta 53:2947-2960

Jenkins MC, Kemp WM (1984) The coupling of nitrification and denitrification in two estuarine sediments. Limnol Oceanogr 29:609-619

Kana TD, Darkangelo C, Hunt MD, Oldham JB, Bennett GE, Cornwell JC (1994) Membrane inlet mass spectrometer for rapid high-precision determination of $\mathrm{N}_{2}, \mathrm{O}_{2}$, and $\mathrm{Ar}$ in environmental water samples. Anal Chem 66:4166-4170

Kana TM, Sullivan MB, Cornwell JC, Groszkowski K (1998) Denitrification in estuarine sediments determined by membrane inlet mass spectrometry. Limnol Oceanogr 43: 334-339

Keough MJ, Ross DJ (1999) Introduced fouling species in Port Phillip Bay. In: Hewitt CL, Cambell DJ, Thresher RE, Martin RB (eds) Marine biological invasions of Port Phillip Bay, Victoria. Centre for Research on Introduced Marine Pests, Technical Report No. 20. CSIRO Marine Research, Hobart, p 193-226

Editorial responsibility: Otto Kinne (Editor-in-Chief), Oldendorf/Luhe, Germany
Kristensen E (1985) Oxygen and inorganic nitrogen exchange in a Nereis virens (polychaete) bioturbated sedimentwater system. J Coast Res 1:109-116

Kristensen E, Jensen MH, Aller RC (1991) Direct measurement of dissolved inorganic exchange and denitrification in individual polychaete (Nereis virens) burrows. J Mar Res 49:355-377

Lohrer D (2003) Burrowing by heart urchins: an important function in soft-sediment ecosystems. Water Atmos 11: $13-14$

Longmore AR, Cowdell RA, Flint R (1996) Nutrient status of the water in Port Phillip Bay. Port Phillip Bay Environmental Study, Technical Report No. 24. CSIRO, Canberra

Murray AG, Parslow JS (1999) Modeling of nutrient impacts in Port Phillip Bay-a semi-enclosed marine Australian ecosystem. Mar Freshw Res 50:597-611

Nicholson GJ, Longmore AR, Cowdell RA (1996) Nutrient status of the sediments of Port Phillip Bay. Port Phillip Bay Environmental Study, Technical Report No. 26. CSIRO, Canberra

Nicholson GJ, Longmore AR, Berelson WM (1999) Nutrient fluxes measured by two types of benthic chamber. Mar Freshw Res 50:567-572

Nielsen LP, Glud RN (1996) Denitrification in coastal sediment measured in situ by the nitrogen isotope pairing technique applied to a benthic flux chamber. Mar Ecol Prog Ser 137:181-186

NRE (2003) Port Phillip Bay Environmental Management Plan. Department of Natural Resources and Environment, Melbourne

Odum EP (1984) The mesocosm. BioScience 34:558-562

Parslow JS, Murray A (1999) Introduced marine species and nitrogen cycling in Port Phillip Bay. In: Hewitt CL, Cambell DJ, Thresher RE, Martin RB (eds) Marine biological invasions of Port Phillip Bay, Victoria. Centre for Research on Introduced Marine Pests, Technical Report No. 20. CSIRO Marine Research, Hobart

Pelegri SP, Nielsen LP, Blackbrun TH (1994) Denitrification in estuarine sediment stimulated by the irrigation activity of the amphipod Corophium volutator. Mar Ecol Prog Ser 105:285-290

Risgaard-Petersen N, Nielsen LP, Revsbech NP (1994) Diurnal variation of denitrification and nitrification in sediments colonized by benthic microphytes. Limnol Oceanogr 39: 573-579

Santschi P, Höhener P, Benoit G, Buchholtz-ten Brink M (1990) Chemical processes at the sediment-water interface. Mar Chem 30:269-315

Sayama M, Kurihara Y (1983) Relationship between burrowing activity of the polychaetous annelid, Neanthes japonica (Izuka) and nitrification-denitrification processes in the sediments. J Exp Mar Biol Ecol 72:233-241

Schindler DW (1998) Replication versus realism: the need for ecosystem-scale experiments. Ecosystems 1:323-334

Seitzinger SP (1988) Denitrification in freshwater and coastal marine ecosystems: ecological and geochemical significance. Limnol Oceanogr 33:702-724

Viollier E, Rabouille C, Apitz SE, Breuer E and 18 others (2003) Benthic biogeochemistry: state of the art technologies and guidelines for the future of in situ survey. J Exp Mar Biol Ecol 285-286:5-31

Vopel K, Thistle D, Rosenberg R (2003) Effect of the brittle star Amphiura filiformis (Amphiuridae, Echinodermata) on oxygen flux into the sediment. Limnol Oceanogr 48: 2034-2045

Submitted: November 17, 2005; Accepted: April 19, 2006

Proofs received from author(s): October 25, 2006 